\title{
Analisis Faktor-Faktor yang Mempengaruhi Permintaan Air Minum PDAM Tirta Sakti Kerinci
}

\author{
Wiyan Mailindra', Azwar Anas ${ }^{2}$ \\ STIE-Graha Karya Muara Bulian ${ }^{1}$ \\ wiyanmailindra@yahoo.co.id \\ STIE-Graha Karya Muara Bulian² \\ azwarzayn@gmail.com
}

\begin{abstract}
This research was carried out using quantitative descriptive method. to determine the factors that affect demand for drinking water PDAM Tirta Sakti Kerinci regency during the years 2003-2017 used multiple linear regression model with melogaritmakan model. From the calculation by using SPSS version 12.0 was obtained coefficient of determination (R2) of 0.984, which means that the model is able to explain the total variation in demand caused by the variable Per Capita Income, Price Water, Number of Customers and Production. From the result, known that variable-free variables Per Capita Income, Price Water, Total Customer and production significantly influence the dependent variable was the demand of drinking water. But if we see a partial, then only the per capita income variable, the variable price of water and production variables that significantly influence the dependent variable was the demand of drinking water. This was seen from test results where the $t$-calculated $t=$ $3.098>1.812$ but has a negative direction for variable income per capita, $t$-count $=2.475>t$ table value $=1.812$ for the variable price of water and $t$-calculated value $=4.805>t$-table $=$ 1.812 for the variable production, because t count $>t$-table, so Ho is rejected. This means that the variable of per capita income, water price variable and the variables significantly affect the production of variable demand (consumption) of drinking water on the PDAM Tirta Sakti Kerinci district.
\end{abstract}

Keyword : water, production, costumers

\section{PENDAHULUAN}

Air adalah sumber kehidupan, karena segala kehidupan di bumi tergantung pada air. Dalam perspektif etika lingkungan, air dengan segala manfaatnya bagi kehidupan menjadi terlalu rendah jika hanya mendapat nilai instrumen. Komisi PBB untuk hak-hak sosial, budaya dan ekonomi menegaskan bahwa air harus diberlakukan sebagai harta sosial dan budaya, bukan sematamata sebagai komoditas ekonomi.

Air merupakan kebutuhan pokok manusia yang harus dikonsumsi setiap hari untuk menjaga kelangsungan hidup. Dalam kehidupan manusia, air memiliki peranan yang sangat penting. Dengan semakin cepatnya tingkat perkembangan pemukiman penduduk suatu kecamatan maupun desa, semakin banyak pula air yang dibutuhkan. Bagi rumah tangga, air bersih dipergunakan untuk minum, mandi, mencuci serta membersihkan rumah dan perabotan lainnya. Disamping keperluan rumah tangga, air juga dipergunakan sebagai penunjang lanjutnya pembangunan seperti keperluan pertanian, pembangkitan tenaga listrik, bahan baku dan bahan pembantu bagi industri-industri dan lain sebagainya. Begitu vitalnya keberadaan air, sehingga manusia selalu berusaha untuk mendapatkannya dalam jumlah yang cukup banyak.

Masyarakat tentu saja merasa kesulitan untuk mendapatkan air tersebut secara benar dan continue. Dengan demikian, air yang digolongkan sebagai barang umum, dimana penggunaannya bebas dilakukan oleh setiap orang dalam jumlah tak terbatas, akhirnya menjadi 
suatu barang yang bernilai ekonomis. Untuk mengatasi permasalahan air bersih sesuai dengan standar kesehatan, maka pemerintah telah mengambil kebijaksanaan dengan menyediakan kebutuhan air tersebut dengan cara mendirikan Perusahaan Daerah Air Minum yang umumnya terdapat di tiap-tiap daerah ditingkat Kecamatan / Kabupaten termasuk daerah Kabupaten Kerinci.

Pada tahun 2013, Kabupaten Kerinci memiliki jumlah penduduk sebesar 235.419 jiwa. Yang terdiri dari beberapa Kecamatan yaitu Kecamatan Gunung Raya, Kecamatan Batang Merangin, Kecamatan Keliling Danau, Kecamatan Danau Kerinci, Kecamatan Sitinjau Laut, Kecamatan Air Hangat, Kecamatan Air Hangat Timur, Kecamatan Depati Tujuh, Kecamatan Gunung Kerinci, Kecamatan Siulak, Kecamatan Kayu Aro, dan Kecamatan Gunung Tujuh. (Kerinci dalam angka, 2013). Dimana daerah Kerinci merupakan daerah yang dikelilingi oleh bukit barisan.

Khususnya kota Sungai Penuh, sebagai Ibu Kota dari Kabupaten Kerinci, fasilitas air bersih merupakan persyaratan yang mutlak, tentu saja dengan tidak melupakan daerah lainnya. Sebagai Ibu Kota Kabupaten, Kota Sungai Penuh tidak hanya berfungsi sebagai pusat pemerintahan, tetapi juga sebagai pusat kesehatan, pendidikan, dan ekonomi di Kabupaten Kerinci. Mengingat letaknya yang strategis, Kota Sungai Penuh berupaya menyediakan infrastruktur air bersih yaitu dengan mendirikan perusahaan air minum yang diberi nama PDAM Tirta Sakti.

PDAM Tirta Sakti sudah seharusnya meningkatkan pelayanan air bersih terutama di Kecamatan-Kecamatan besar, hal ini disebabkan karena pandangan dan pengetahuan masyarakat terhadap air sumur sering keliru. Mereka menganggap air sumur mudah tercemar karena tidak dimurnikan terlebih dahulu dan kepemilikan tanah yang sempit menyebabkan jarak ideal antara sumur dan tempat pembuangan kotoran tidak memenuhi syarat, sehingga memungkinkan terjadinya pencemaran air sumur oleh kuman-kuman menjadi sangat tinggi. Apabila perusahaan air minum mampu menyalurkan lebih banyak air bersih kepada penduduk, maka kesejahteraan penduduk dapat ditingkatkan dan kesehatan masyarakat akan menjadi lebih baik, karena sifat hakikatnya barangbarang umum dan jasa-jasa yang memberikan keuntungan langsung sama sekali tidak akan diproduksilan oleh swasta akan tetapi diusahakan oleh pemerintah berhubungan dengan pengaruh-pengaruh ekonomi.

Berkaitan dengan kondisi tersebut sesuai dengan teori permintaan berikut ini : Jumlah barang atau produk yang diminta oleh konsumen merupakan sesuatu jumlah barang yang ingin dibeli oleh konsumen ketika menghadapi berbagai hal, yaitu : harga barang yang diinginkan, harga barang lain yang terkait, pendapatan, selera, dan segala sesuatu yang terkait dengan keinginan konsumen. Keinginan konsumen dapat berbeda dengan kondisi aktual dari jumlah barang yang sesungguhnya dibeli oleh konsumen. Dengan demikian, bahwa permintaan suatu produk atau komoditi tergantung pada kebutuhan konsumen terhadap komoditi tersebut, air merupakan suatu produk yang dibutuhkan oleh masyarakat dalam menjalani aktivitasnya sehari-hari.

$$
\text { Dalam rangka memenuhi }
$$

kebutuhan masyarakat sebagai konsumen terhadap pengadaan dan penyaluran air minum di Kabupaten Kerinci, dilaksanakan oleh Perusahaan Daerah Air Minum PDAM Tirta Sakti Kabupaten Kerinci yang bertujuan untuk menjamin air yang memenuhi persyaratan kebersihan dan kesehatan. Seperti yang telah dijelaskan sebelumnya, adapun semua kebijakan yang telah diambil pemerintah Kabupaten Kerinci terhadap konsumen air bersih tentunya dengan pertimbangan dan memperhatikan faktor-faktor eksternal yang dianggap sangat berpengaruh 
terhadap permintaan air bersih di Kabupaten Kerinci. Faktor-faktor yang mempengaruhi permintaan air bersih secara umum antara lain : Harga barang itu sendiri, harga barang subsidi, pendapatan rumah tangga, dan pendapatan rata-rata masyarakat, distribusi pendapatan, cita rasa masyarakat, jumlah penduduk, dan ramalan mengenai masa yang akan datang. Sedangkan di Kabupaten kerinci permintaan air minum hanya dipengaruhi oleh empat faktor, yaitu: pendapatan perkapita masyarakat, harga air, jumlah pelanggan dan produksi. Semua faktor harus dapat diintegrasikan antara satu dengan yang lainnya untuk mencapai tujuan perusahaan. Dimana peningkatan permintaan air minum ini tidak terlepas dari adanya peningkatan jumlah penduduk di Kabupaten Kerinci selama tahun 20132017. Selain itu, juga disebabkan oleh peningkatan harga air yang tidak terlalu besar sehingga tidak memberatkan masyarakat.

Bertolak dari fakta yang terpapar sebelumnya, bahwa PDAM Tirta Sakti terus berupaya untuk meningkatkan pelayanannya kepada masyarakat. Hal ini menjadi fenomena yang menarik karena tidak mudah untuk mengajak masyarakat Kabupaten Kerinci untuk membayar sesuatu yang sebelumnya mereka dapatkan secara gratis. Keberhasilan PDAM Tirta Sakti Kabupaten Kerinci adalah dalam mengubah persepsi bahwa air minum menjadi barang ekonomis bagi masyarakat Kabupaten Kerinci, dan permintaan terhadap air minum tidak lagi didasarkan pada kebutuhan semata, melainkan akan ditentukan oleh faktor-faktor lainnya, baik faktor sosial maupun faktor ekonomi.

\section{METODE PENELITIAN}

Dalam penelitian karena belum diketahui apakah permintaan masyarakat terhadap sektor air minum berbentuk linier atau non linier, maka dalam pembahasannya akan digunakan pengujian dalam bentuk linier atau non linier. Jumlah variabel yang dipakai ada 4 maka untuk mendapat koefisien-koefisien yang dibutuhkan akan dipergunakan paket program SPSS versi 12,0. Adapun dalam bentuk linier fungsi permintaan tersebut dapat ditulis sebagai berikut :

$$
\mathrm{Qd}=\mathrm{b0}+\mathrm{b} 1 \mathrm{Yc}+\mathrm{b} 2 \mathrm{Ha}+\mathrm{b3} \mathrm{JP}+\mathrm{b4} \mathbf{P}+\mu
$$

Sedangkan dalam bentuk non linier dapat di tulis (double logaritma), fungsi tersebut dapat di tulis menjadi:

$$
\log \mathbf{Q d}=\beta 0+\beta 1 \log Y c-\beta 2 \log \mathrm{Ha}+\beta 3 \log \mathrm{JP}+\beta 4 \log \mathrm{P}+\mu
$$

Pada fungsi yang bersifat non linier ini penggunaannya dikalikan dengan asumsi adanya elastisitas yang konstanta antara variabel independen. Pada fungsi non linier ini koefisien regresi dapat langsung menjadi elastisitasnya.

\section{HASIL DAN PEMBAHASAN Analisis Deskriptif}

Peningkatan permintaan air minum oleh PDAM Tirta Sakti Kabupaten Kerinci cenderung fluktuatif dan cenderung mengalami peningkatan setiap tahunnya karena tidak terlepas dari adanya beberapa faktor-faktor yang sangat mempengaruhinya seperti : pendapatan perkapita masyarakat, harga air, jumlah pelanggan dan produksi di Kabupaten Kerinci selama tahun 1994-2008. Corak distribusi pendapatan masyarakat Kabupaten Kerinci yang selalu berubahubah menyebabkan perubahan pula dalam permintaan air minum, selain itu juga disebabkan oleh peningkatan harga air yang tidak terlalu besar sehingga tidak memberatkan masyarakat, jumlah 
pelanggan yang terus meningkat memungkinkan terjadinya pertambahan permintaan air minum pada PDAM Tirta Sakti, dan semakin baiknya produksi air minum yang dihasilkan dapat mendorong masyarakat untuk lebih meningkatkan permintaan terhadap daya beli air minum itu sendiri. Untuk memahami mengenai perkembangan permintaan air minum ini dapat dilihat pada tabel berikut :

Tabel 1. Perkembangan permintaan air minum

\begin{tabular}{ccc}
\hline Tahun & Permintaan Air Minum $\left(\mathrm{M}^{3}\right)$ & Perkembangan $(\%)$ \\
\hline 2003 & 2.167 .844 & - \\
2004 & 2.222 .456 & 2,52 \\
2005 & 2.395 .376 & 7,78 \\
2006 & 2.675 .216 & 11,68 \\
2007 & 2.844 .651 & 6,33 \\
2008 & 3.402 .026 & 19,59 \\
2009 & 3.367 .259 & $-1,02$ \\
2010 & 3.857 .612 & 14,56 \\
2011 & 4.248 .077 & 10,12 \\
2012 & 4.350 .461 & 2,41 \\
2013 & 4.441 .588 & 2,09 \\
2014 & 4.307 .831 & $-3,01$ \\
2015 & 4.269 .658 & $-0,89$ \\
2016 & 4.434 .198 & 3,85 \\
2017 & 4.462 .981 & 0,65 \\
& Rata-rata Pertahun & 5,11 \\
\hline
\end{tabular}

Sumber : BPS Provinsi jambi 2018

\section{Perkembangan Pendapatan Perkapita Masyarakat di Kabupaten Kerinci}

Pendapatan perkapita merupakan salah satu indikator yang menunjukkan tingkat ekonomi penduduk suatu daerah. PDRB kalau dibagi dengan jumlah penduduk pertengahan tahun yang bersangkutan merupakan PDRB perkapita, sedangkan Pendapatan Regional Perkapita adalah PDRB atas dasar biaya faktor dibagi jumlah penduduk pertengahan tahun.
Namun demikian penghitungan pendapatan perkapita dari PDRB tersebut masih berbeda dengan Pendapatan Nasional Perkapita, hal ini dikarenakan kesulitan dalam memperoleh berbagai data yang diperlukan seperti pendapatan yang mengalir keluar masuk, besarnya keuntungan yang tidak dibagikan dan sebagainya. Untuk lebih jelasnya perhatikan tabel 2. perdapatan perkapita Kabupaten Kerinci selama periode 19942008 berikut ini :

Tabel 2. Perkembangan Pendapatan Perkapita Masyarakat Kabupaten Kerinci

\begin{tabular}{ccc}
\hline Tahun & Pendapatan Perkapita ( Rp ) & Perkembangan (\%) \\
\hline 2003 & $2.222 .632,95$ & - \\
2004 & $2.489 .455,63$ & 12,00 \\
2005 & $2.590 .143,78$ & 4,04 \\
2006 & $2.660 .753,11$ & 2,73 \\
2007 & $2.745 .537,22$ & 3,19 \\
2008 & $2.986 .350,41$ & 8,77 \\
2009 & $3.391 .206,45$ & 13,56 \\
2010 & $3.891 .839,10$ & 14,76
\end{tabular}




$\begin{array}{ccc}2011 & 4.770 .005,59 & 22,56 \\ 2012 & 5.734 .360,28 & 20,22 \\ 2013 & 6.520 .126,49 & 13,70 \\ 2014 & 7.514 .022,85 & 15,24 \\ 2015 & 8.538 .979,62 & 13,64 \\ 2016 & 9.727 .071,46 & 13,91 \\ 2017 & 10.136 .812,67 & 4,21 \\ & \text { Jumlah } & 10,84\end{array}$

Sumber : BPS Provinsi jambi 2018.

Perkembangan Harga Air Minum PDAM Tirta Sakti Kabupaten Kerinci

Kebijaksanaan penetapan harga air minum yang dilakukan oleh PDAM Tirta Sakti Kabupaten Kerinci didasarkan pada kebijaksanaan pemerintah Daerah. Dimana perkembangan dari perusahaan ini merupakan tanggung jawab Pemerintah.

Pemerintah daerah didalam melakukan penetapan harga air minum ini biasanya didasarkan pada perkembangan biaya produksi. Kemudian ditinjau pula dari keadaan tingkat perekonomian daerah. Jadi berdasarkan ini pula pemerintah dapat mengambil suatu kebijaksanaan perubahan kenaikan dan penetaan harga air minum di PDAM Tirta Sakti. Adapun perkembangan harga air minum pada PDAM Tirta Sakti dapat dilihat pada tabel berikut ini :

Tabel 3. Perkembangan Harga Air Minum PDAM Tirta Sakti Kabupaten Kerinci

\begin{tabular}{ccc}
\hline Tahun & Harga Air $\left(\mathrm{Rp} / \mathrm{M}^{3}\right)$ & Perkembangan \\
\hline 2003 & 400 & - \\
2004 & 400 & 0 \\
2005 & 400 & 0 \\
2006 & 400 & 0 \\
2007 & 450 & 12,50 \\
2008 & 450 & 0 \\
2009 & 540 & 20,00 \\
2010 & 540 & 0 \\
2011 & 800 & 48,15 \\
2012 & 800 & 0 \\
2013 & 1200 & 50,00 \\
2014 & 1200 & 0 \\
2015 & 1200 & 0 \\
2016 & 1200 & 0 \\
2017 & 1200 & 0 \\
& Rata-rata & 8,71 \\
\hline
\end{tabular}

Sumber :PDAM Tirta Sakti Kabupaten Kerinci 2017

Pengaruh secara bersama-sama Variabel Pendapatan Perkapita, Harga Air, Jumlah Pelanggan dan Produksi Terhadap Permintaan Air Minum

Pada bab tiga dalam metode analisis data telah dikemukakan bahwa untuk melihat pengaruh dari variabelvariabel pendapatan perkapita (Yc), Harga air (Ha), Jumlah Pelanggan (JP) dan
Produksi (P) secara bersama-sama terhadap permintaan air minum pada PDAM Tirta sakti Kabupaten Kerinci digunakan alat analisis regresi linier berganda. Model ini menunjukan pula hubungan antara konsumsi air minum dengan variabel Pendapatan Perkapita (Yc), Harga Air (Ha), Jumlah Pelanggan (JP) dan Produksi (P). Dimana Qd 
(Permintaan Air Minum), sebagai variabel dependent, sedangkan (Yc) Pendapatan Perkapita, (Ha) Harga Air, (JP) Jumlah
Pelanggan dan Produksi (P) sebagai variabel independen masing seperti yang terlihat ada persamaan di bawah ini.

Tabel 4. Hasil Perhitungan Regresi Linear Berganda.

\begin{tabular}{lcccccc}
\hline Variabel & Koefisien & $\begin{array}{c}\text { Standar } \\
\text { Error }\end{array}$ & t-hitung & $\begin{array}{c}\text { t-tabel } \\
\alpha=5 \% \\
\mathrm{df}=10\end{array}$ & F-hitung & $\mathrm{R}^{2}$ \\
\hline Konstanta & 0,2382 & 394 & 6,043 & 1,812 & 154,065 & 0,984 \\
Yc & $-0,364$ & 117 & $-3,098$ & & & \\
Ha & 0,263 & 106 & 2,475 & & & \\
JP & 0,251 & 228 & 1,100 & & & \\
P & 0,707 & 147 & 4,805 & & & \\
\hline
\end{tabular}

Untuk melihat apakah perhitungan regresi linear berganda merupakan penduga yang sesuai maka diperlukan perhitungan untuk melihat besarnya koefisien determinasi $\left(\mathrm{R}^{2}\right)$.

Dari hasil perhitungan melalui komputer diperoleh besarnya nilai koefisien determinasi $\left(\mathrm{R}^{2}\right)$ sebesar 0,984. Sehingga dapat dikatakan bahwa model yang digunakan mampu menjelaskan 98,4 persen variasi total dalam respon yang disebabkan oleh kombinasi linier dari variabel-variabel pendapatan perkapita, harga air, jumlah pelanggan dan Produksi atau dengan kata lain $\mathrm{R}^{2}$ sebesar 0,984 persen menyatakan bahwa 98,4 variasi dari variabel permintaan air minum disebabkan oleh kombinasi linear dari variabel pendapatan perkapita, harga air, jumlah pelanggan dan Produksi Sedangkan sisanya sebesar 0,016 atau sebesar 1,6 persen disebabkan oleh variabel lain yang tidak diamati dalam variabel ini.

Untuk melihat apakah model prediksi garis regresi linier berganda tersebut benar-benar signifikan atau berarti secara statistik, maka diperlukan Uji F. Dengan melalui perhitungan dengan bantuan peralatan program SPSS versi 12,0 diperoleh besarnya nilai F-hitung sebesar 154,065 dan $\mathrm{F}$ tabel dengan derajat keyakinan yang digunakan $\alpha=5 \%(0,05$; $10 ; 4)$ adalah 3,48 .
Dengan membandingkan besarnya nilai F-hitung dengan F-tabel diatas ternyata F-hitung $=154,065>3,48$ karena F-hitung > F-tabel, maka Ho ditolak. Ini berarti bahwa model garis regresi berganda tersebut adalah benar. Sehingga dengan demikian hipotesis yang menyatakan bahwa terdapat pengaruh yang signifikan antara variabel pendapatan perkapita, harga air, jumlah pelanggan dan Produksi terhadap permintaan air minum adalah benar.

\section{PEMBAHASAN}

Besarnya Pengaruh Masing-Masing Faktor terhadap Konsumsi Air Minum Pada PDAM Tirta Sakti Kabupaten Kerinci.Tujuan dari pembahasan bagian ini adalah Untuk melihat signifikan atau tidak signifikan variabel-variabel pendapatan perkapita, harga air ,jumlah pelanggan dan Produksi dan Untuk melihat variabel independen yang mana mempunyai pengaruh yang paling besar terhadap permintaan air minum.

Tujuan diatas diwujudkan dengan melakukan pengujian dengan menggunakan analisis regresi linier berganda dengan melihat koefisien regresi parsialnya. Berdasarkan hasil perhitungan maka koefisien-koefisien regresi dari variabel pendapatan perkapita, harga air, jumlah pelanggan dan Produksi dapat dilihat pada tabel berikut : 
Tabel 5. Besarnya Pengaruh Masing-Masing Faktor Terhadap Konsumsi Air Minum PDAM Tirta Sakti Kabupaten Kerinci.

\begin{tabular}{ccc}
\hline Variabel Independent & Koefisien Regresi & $\mathrm{T}(\mathrm{df}=10)$ \\
\hline Yc & $-0,364$ & $-3,098$ \\
$\mathrm{Ha}$ & 0,263 & 2,475 \\
$\mathrm{JP}$ & 0,251 & 1,100 \\
$\mathrm{P}$ & 0,707 & 4,805 \\
\hline
\end{tabular}

Sumber : Data Diolah

Dari hasil perhitungan dengan bantuan SPSS versi 12,0 diperoleh nilai thitung untuk untuk masing-masing variabel sebagai berikut :

1. Variabel Pendapatan Perkapita

Dari hasil perhitungan didapat besarnya nilai t-hitung untuk variabel pendapatan perkapita adalah sebesar 3,098 sedangkan nilai t-tabel dengan derajat keyakinan sebesar $\alpha=5 \%$ untuk pengujian searah diperoleh nilai 1,812. Dengan demikian nilai t-hitung $=3,098>$ nilai $\mathrm{t}$-tabel $=1,812$ karena t-hitung > t-tabel, maka Ho ditolak Ini berarti bahwa variabel pendapatan perkapita berpengaruh secara signifikan terhadap variabel permintaan air minum, namun memiliki arah yang negatif.

2. Variabel Harga Air

Dari hasil perhitungan didapat besarnya nilai t-hitung untuk variabel Harga Air adalah sebesar 2,475 sedangkan nilai t-tabel dengan derajat keyakinan sebesar $\alpha=5 \%$ untuk pengujian searah diperoleh nilai 1,812 dengan demikian nilai t-hitung $=2,475$ $>$ nilai $\mathrm{t}$-tabel $=1,812$ karena $\mathrm{t}$-hitung $>$ t-tabel. maka Ho ditolak. Ini berarti bahwa variabel Harga Air berpengaruh secara signifikan terhadap variabel permintaan air minum.

3. Variabel Jumlah Pelanggan

Dari hasil perhitungan didapat besarnya nilai t-hitung untuk variabel Jumlah Pelanggan adalah sebesar 1,100. Sedangkan nilai t-tabel dengan derajat keyakinan sebesar $\alpha=5 \%$ untuk pengujian searah diperoleh nilai 1,812. Dengan demikian nilai t-hitung $=1,100<\mathrm{t}$-tabel $=1,812$ karena $\mathrm{t}-$ hitung < t-tabel, maka Ho diterima. Ini berarti bahwa variabel Jumlah Pelanggan tidak berpengaruh secara signifikan terhadap variabel permintaan air minum.

4. Variabel Produksi

Dari hasil perhitungan didapat besarnya nilai t-hitung untuk variabel Produksi adalah sebesar 4,805. Sedangkan nilai t-tabel dengan derajat keyakinan sebesar $\alpha=5 \%$ untuk pengujian searah diperoleh nilai 1,812 . Dengan demikian nilai t-hitung = 4,805 $>$ t-tabel $=1,812$ karena t-hitung $>$ t-tabel, maka Ho ditolak. Ini berarti bahwa variabel Produksi berpengaruh secara signifikan terhadap variabel permintaan air minum.

Dari keempat variabel diatas secara parsial diketahui bahwa variabel pendapatan perkapita, variabel harga air dan variabel produksi berpengaruh secara signifikan terhadap variabel permintaan air minum sedangan variabel jumlah pelanggan tidak berpengaruh secara signifikan terhadap variabel konsumsi air minum.

Adapun variabel pendapatan perkapita berpengaruh secara negatif terhadap permintaan air minum pada PDAM Tirta Sakti karena pada umumnya pendapatan rata-rata masyarakat Kabupaten Kerinci itu pada tingkat menengah keatas yang menyebabkan mereka lebih cenderung memilih menggunakan sumur bor dari pada membeli air dari PDAM, sebab banyak sekali kendala-kendala yang ditimbulkan oleh PDAM itu sendiri, seperti kecilnya aliran air yang mengalir keruma-rumah, belum lagi seringnya terjadi "Air 
mati"yang tidak mengalir sehingga masyarakat enggan untuk membeli air dari PDAM Tirta Sakti dan lebih cenderung menggunakan sumur bor karena penggunaannya lebih baik.

Adapun pengaruh positif harga air terhadap permintaan air minum di Kabupaten Kerinci ini disebabkan karena perusahaan PDAM Tirta Sakti ini termasuk dalam kategori pasar monopoli. Dimana perusahaan Tirta Sakti merupakan perusahaan monopoli satu-satunya yang bergerak dibidang air minum yang berada di Kabupaten Kerinci sehingga penentuan harga air dapat dikuasainya. Dengan demikian maka para konsumen tidak mempunyai pilihan lain bila menginginkan air minum selain membeli pada perusahaan PDAM tersebut pada tingkat harga berapapun yang di tawarkan. Hal ini juga mungkin disebabkan oleh penetapan harga air yang dilakukan oleh PDAM Tirta Sakti didasarkan pada kebijaksanaan Pemerintah Daerah. Pemerintah Daerah didalam melakukan penetapan harga air minum ini biasanya didasarkan pada perkembangan biaya produksi dan keadaan tingkat perekonomian daerah. Dengan demikian penetapan air minum ini oleh PDAM Tirta Sakti tidak semata-mata mengutamakan keuntungan perusahaan akan tetapi juga kesejahteraan masyarakat. Hal inilah yang pada akhirnya mempengaruhi permintaan air minum.

Adapun signifikannya variabel produksi terhadap permintaan air minum pada PDAM Tirta Sakti Kabupaten Kerinci adalah karena kelancaran aliran air dari sumber mata air itu sendiri yang menyebabkan produksi air minum oleh PDAM tersebut berjalan secara efisien yang pada hakikatnya memberi kepuasan optimum bagi konsumen. Akibat adanya kepuasan inilah permintaan air minum oleh masyarakat, semakin meningkat sehingga hal ini mendorong perusahaan PDAM Tirta Sakti meningkatkan produksinya untuk mencari tingkat yang maksimum guna memenuhi kebutuhan masyarakat luas.
Ketidaksignifikannya variabel jumlah pelanggan terhadap permintaan air minum pada PDAM Tirta Sakti walaupun PDAM Tirta Sakti mengalami pertambahan jumlah pelanggan namun pemakaian air PDAM sedikit karena dalam keluarga banyak mengkonsumsi air dari sumber lain seperti sungai dan sumur.

Selanjutnya dengan melihat nilai koefisiensi regresi dari pendapatan perkapita, harga air, jumlah pelanggan dan Produksi dapat dilihat pengaruh variabel pendapatan perkapita, harga air, jumlah pelanggan dan Produksi terhadap permintaan air minum. Dimana pendapatan perkapita (Yc) berpengaruh terhadap variabel (Qd) permintaan air minum sebesar -0,364. Ini berarti bahwa setiap terjadi penurunan pendapatan perkapita sebesar $10 \%$ maka permintaan air minum akan turun sebesar 3,64 \% atau dengan kata lain permintaan air minum akan turun sebesar 3,64 \%. Variabel harga air berpengaruh terhadap variabel (Qd) permintaan air minum adalah sebesar 0,263 . Ini berarti bahwa setiap terjadi kenaikan harga air sebesar $10 \%$ maka permintaan air minum akan naik sebesar $2,63 \%$ atau dengan kata lain permintaan air minum akan turun sebesar 2,63\%. Pada variabel Jumlah Pelanggan dimana variabel Jumlah Pelanggan (JP) tidak berpengaruh terhadap variabel (Qd) permintaan air minum adalah sebesar 0,251. Ini berarti bahwa setiap terjadi kenaikan Jumlah Pelanggan sebesar $10 \%$ maka permintaan air minum akan naik sebesar 2,51 \% atau dengan kata lain permintaan air minum akan naik sebesar 2,51\%. Variabel Produksi berpengaruh terhadap variabel (Qd) permintaan air minum adalah sebesar 0,707. Ini berarti bahwa setiap terjadi kenaikan harga air sebesar $10 \%$ maka permintaan air minum akan naik sebesar 7,07 \% atau dengan kata lain permintaan air minum akan naik sebesar 7,07\%. 


\section{SIMPULAN}

Dari analisa yang telah diterangkan pada bab sebelumnya, dapat diambil kesimpulan sebagai berikut : (1) Permintaan terhadap air minum PDAM Tirta Sakti Kabupaten Kerinci selama periode 1994-2008 mengalami fluktuasi. Adapun jumlah permintaan air minum di Kabupaten Kerinci mengalami perkembangan rata-rata sebesar 7,13\% pertahun (2) Diketahui faktor-faktor yang mempengaruhi permintaan air minum di PDAM Tirta Sakti Kabupaten Kerinci ada 4 (Empat) variabel yaitu pendapatan perkapita, harga air, jumlah pelanggan dan produksi. Dimana secara simultan keempat variabel di atas berpengaruh signifikan terhadap variabel terikat yaitu permintaan air minum. Hal ini ditunjukkan oleh uji $\mathrm{F}$, yaitu F-hitung $=154,065>$ F-tabel yaitu 3,48 . Sedangkan secara parsial hanya 3 variabel yaitu variabel pendapatan perkapita, variable harga air dan variabel produksi yang berpengaruh secara signifikan terhadap variabel terikat yaitu permintaan air minum sebesar $\mathrm{t}$-hitung $=$ 3,098 > t-tabel 1,812 namun memiliki arah yang negatif untuk variable pendapatan perkapita, t-hitung $=2,475>$ t-tabel yaitu 1,812 untuk variabel harga air dan t-hitung $=4,805>\mathrm{t}$-tabel yaitu 1,812 untuk variable produksi.

\section{DAFTAR PUSTAKA}

Agusriyani, Ratumas, 2005, 'Faktor-faktor yang Mempengaruki Permintaa Impor Propinsi Jambi Priode 19902003"

Arsyad, Lincolin,1987, Ikhtisar Teori dan Soal Jawaban Ekonomi Mikro,BPFE, Yogyakarta.

Baudiono, 1982, Pengantar Ilmu Ekonomi. Ekonomi Makro,BPFE,Jakarta.

Billas, A, Richard,1994, Teori Ekonomi Mikro Edisi kedua. Erlangga, Jakarta

BPS. 1998-2008. Jambi Dalam Angka. 1998-2008. Jambi.

BPS.1998-2008. PDRB. 1998-2008. Jambi.
Gilarso,T,1993,Pengantar Ilmu Ekonomi, Canisius, Yogyakarta.

Kusumosuwidro, Sisdjiotmo, 1990, Pengantar Teori Ekonomi Mikro, Rineka Cipta, Jakarta

Nazir, Muhammad,1988, Metode Penelitian, Jakarta. Ghalia Indonesia.

Safitri, Susria,2008, Faktor-faktor yang mempengaruhi permintaan air minum PDAM Tirta Mayang oleh masyarakat Koto Jambi,Skripsi. Universitas Jambi.

Silaan,Vindi Violan, 2005, “Analisis Faktor-faktor Yang Mempengaruhi

Permintaan Motor di Kec. Kotabaru Jambi (Studi Kasus Kel.Simp III Sipin)"

Sudarman,A, 1989, Teori Ekonomi Mikro, jilid I, BPFE, Yogjakarta.

Sukirno, Sadono,1985.Pengantar Teori Mikro Ekonomi. FE UI, Bina Grafika.

Sukirno, Sadono,1994.Pengantar Teori Mikro Ekonomi. PT, Raja Grafindo persada.

Sunantoro, 2005, “Faktor-faktor Yang Mempengaruhi Permintaan Premi Asuransi Jiwa pada Asuransi Jiwa Bersama Buniputera 1912 Jambi"

Sudarsono,1986, Pengantar Ekonomi Mikro, LP3ES, Jakarta

Winardi, 1988, Teori Ekonomi, Transito, Bandung. 